Discussion Paper No. 11-046

\title{
Why Training Older Employees is Less Effective
}

Thomas Zwick

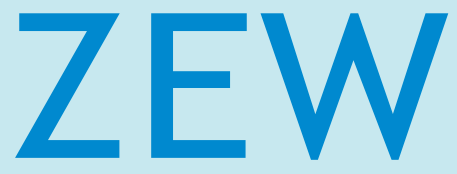

Zentrum für Europäische Wirtschaftsforschung $\mathrm{GmbH}$

Centre for European

Economic Research 


\title{
Discussion Paper No. 11-046 \\ Why Training Older Employees is Less Effective
}

\author{
Thomas Zwick
}

Download this ZEW Discussion Paper from our ftp server:

http://ftp.zew.de/pub/zew-docs/dp/dp11046.pdf

Die Discussion Papers dienen einer möglichst schnellen Verbreitung von neueren Forschungsarbeiten des ZEW. Die Beiträge liegen in alleiniger Verantwortung der Autoren und stellen nicht notwendigerweise die Meinung des ZEW dar.

Discussion Papers are intended to make results of ZEW research promptly available to other economists in order to encourage discussion and suggestions for revisions. The authors are solely responsible for the contents which do not necessarily represent the opinion of the ZEW. 


\section{Non-technical Summary}

The ageing of the workforce increases the importance of life-long learning for competitiveness. Most contributions on continuing training focus on lower participation of older employees. This paper in contrast concentrates on changes in the effectiveness of training during the life cycle. It shows that training of older employees is less effective in the self-assessment of training participants. Training effectiveness is measured with respect to key dimensions such as career development, earnings, adoption of new skills, flexibility, or job security. Older employees also pursue less ambitious goals with their training participation. An important reason for these differences during the life cycle is that firms do not offer the "right" training forms and contents. Older employees prefer and get higher returns from informal and self-determined training with a clear focus on practical and relevant work problems. They also profit more from training contents that can mainly be tackled by crystallised abilities such as communication and management skills. Training incidence in the more effective training forms is however not higher for older employees. Given that other decisive variables on training effectiveness such as training duration, financing and initiative do not change over the life cycle, the wrong allocation of training contents and training forms seems to be a critical reason for the lower effectiveness of training. The data basis is detailed answers of more than 5000 German training participants. This contribution uses multi-variate regressions on training participation and effectiveness. Besides age, it takes into account many covariates that may be correlated with training effectiveness and age such as tenure, health, qualification and intention to quit the labour force soon. 


\section{Nichttechnische Zusammenfassung}

Die Alterung der Belegschaften erhöht den Stellenwert lebenslangen Lernens für die Wettbewerbsfähigkeit der Unternehmen. Die meisten Beiträge zur Weiterbildung Älterer beziehen sich bisher auf deren relativ niedrige Teilnahme. Dieses Papier konzentriert sich hingegen auf die Effektivität von Weiterbildung im Laufe des Berufslebens. Es zeigt, dass die Weiterbildung älterer Beschäftigter in deren Selbstwahrnehmung weniger effektiv ist. Die Effektivität wird in Bezug auf Schlüsseldimensionen wie Karriereentwicklung, Einkommenssteigerungen, Erwerb neuen Wissens, Flexibilität oder Arbeitsplatzsicherheit gemessen. Ältere Beschäftigte verbinden zudem weniger ambitionierte Ziele mit der Weiterbildungsteilnahme. Ein wichtiger Grund für diese Unterschiede ist, dass die Unternehmen nicht die „richtigen“ Weiterbildungsformen und Weiterbildungsinhalte anbieten. Gemäß theoretischen Überlegungen bevorzugen ältere Beschäftigte informelle Weiterbildung mit einem klaren Bezug zu praktischen und zeitnahen Problemen am Arbeitsplatz. Sie profitieren zudem eher von Weiterbildungsinhalten, die leichter mit krystallisierten Fähigkeiten bewältigt werden können, wie beispielsweise Kommunikations- und Managementtraining. Die Teilnahme älterer Beschäftigter an diesen effektiveren Weiterbildungsformen ist jedoch nicht höher. Andere Weiterbildungscharakteristiken wie beispielsweise Dauer, Finanzierung und die Marktseite von der die Initiative für die Weiterbildung ausgeht, sind überraschend ähnlich für alle Altersgruppen. Deshalb ist die falsche Allokation von Weiterbildungsinhalten und -formen ein wichtiger Grund für die geringere Effektivität bei älteren Beschäftigten. 


\title{
Why Training Older Employees is Less Effective
}

\author{
Thomas Zwick ${ }^{\text {a), b) }}$ \\ July 2011 \\ a) Centre for European Economic \\ Research (ZEW) \\ L7,1 \\ D-68161 Mannheim \\ ${ }^{b}$ Ludwig-Maximilians-University \\ (LMU) Munich \\ Munich School of Management \\ Ludwigstr. 28/RG \\ D-80539 Munich \\ E-Mail: zwick@bwl.lmu.de
}

Key-Words: Training, Older Employees, Linked-Employer-Employee Data

JEL Codes: J10, J24, J28

$\diamond$ I thank David Bills, Ruth Kanfer, Christian Stamov-Rossnagel, Ursula Staudinger, and Sven Voelpel for helpful comments. I also thank the Research Data Centre (FDZ) of the Federal Employment Agency at the Institute for Employment Research for the provision of the data set and its useful documentation. The data basis of this publication is the "Berufliche Weiterbildung als Bestandteil Lebenslangen Lernens" panel data set (WeLL) (first two waves). Data access was via the scientific user file provided by FDZ. 


\begin{abstract}
This paper shows that training of older employees is less effective. Training effectiveness is measured with respect to key dimensions such as career development, earnings, adoption of new skills, flexibility or job security. Older employees also pursue less ambitious goals with their training participation. An important reason for these differences during the life cycle might be that firms do not offer the "right" training forms and contents. Older employees get higher returns from informal and directly relevant training and from training contents that can be mainly tackled by crystallised abilities. Training incidence in the more effective training forms is however not higher for older employees. Given that other decisive variables on effectiveness such as training duration, financing and initiative are not sensitive to age, the wrong allocation of training contents and training forms therefore is critical for the lower effectiveness of training.
\end{abstract}




\section{Introduction}

Most papers on continuing training for older employees concentrate on their lower training incidence (Taylor and Unwin, 2001; D'Addio et al., 2010). Obviously, it is a problem in a greying economy when older employees get less training because a lack of training negatively affects their productivity and employability. The main reasons for the lower training incidence of older employees proposed in the literature are the shorter amortisation period of investments (Cunha et al., 2006), their lower motivation to invest in training (Warr and Fay, 2001) and a perceived lower adaptability of older employees (Warr, 1993).

Less attention has been given to the question whether and why training measures for older employees are less effective than for younger employees. Some contributions for example argue that training for older employees is not effective in increasing the relative productivity of older employees (Göbel and Zwick, 2010). Relatively well researched is the training supply side - personnel managers might think that older employees are less able or willing to learn (Warr and Birdi, 1998). Mainly caused by a lack of data, we do not know very much about the demand side - the opinion of older training participants. This paper therefore uses recently available German linked employer-employee data (WeLL) to analyse age patterns in characteristics and selfreported effectiveness for those employees who participate in training.

The paper is organised as follows: the next section presents a short overview on the literature on age differences in training. The third section describes the data set and the empirical strategy. The fourth section discusses the main hypothesis that older employees prefer different training contents and training forms and the main reason for 
the low effectiveness of their training is that firms do not take their preferences into account. The fifth section concludes.

\section{Background}

Since many years less than ten percent of German enterprises indicate that they offer training for older employees. Only around one fourth of these enterprises has specific training measures for older employees (Bellmann and Leber, 2004; Göbel and Zwick, 2010). ${ }^{1}$ Lower training participation of older employees may be a consequence of differences between older and younger employees with respect to qualification levels, gender or other training relevant characteristics. Tippelt et al. (2009) for example show that female, lower educated, older or sick employees participate significantly less in continuing training. We also know that employment is a crucial pre-requisite for training - the older the lower is the relative training participation of the unemployed compared with the employed (Alferoff, 1999; Von Rosenbladt and Bilger, 2008). The complete attribution of training differences to age in bivariate descriptive statistics therefore might create artefacts (Gallenberger, 2002). We therefore need a multivariate approach in order to measure unbiased correlations between age and training.

Work motivation does not necessarily decline with age - motivation for some tasks such as training may however be negatively affected by age. Warr (2001) for example argues in a theoretical model that work motivation is influenced by incentives, habits, the comparison with (younger) peers, and social pressure. Older workers might be less motivated to participate in training because (financial) incentives are lower than for younger employees or comparable incentives are less attractive. Training might be

\footnotetext{
${ }^{1}$ The share of training establishments and the share of employees trained in Germany are on average comparable with other European countries (Bannwitz (2008). Also the difference of nine percent in training participation of older employees (aged 55 years or older) in comparison to all employees is exactly at the average value of all countries of the European Union.
} 
perceived as unwelcome break of routines that are more entrenched for older employees (especially when they did not have training for a long period of time). A comparison of training effectiveness with younger peers might be unfavourable for older employees because the capacity to learn declines in some dimensions. Finally, the social pressure to participate in training might be lower than for younger employees. There has been little empirical research, however, whether employers make an attempt to adopt the training design and methods to suit the preferences of older employees (ArmstrongStassen and Templer, 2005).

Stamov-Rossnagel and Hertel (2010) stress that older employees mainly want to match their resources to external demands. Younger people primarily strive for gains, older people however more often focus on maintenance, harvesting of prior investment returns, and the prevention of losses. The authors argue that interest in tasks that involve acquiring new skills, knowledge or career opportunities should decrease with age. Motives such as autonomy, positive relationships with colleagues and supervisors, and self-realisation increase in importance during the life cycle. Callahan et al. (2003) accordingly find in their meta-analysis that a clear motivation why training measures are necessary with respect to relevant work problems increases older learner training performance. This might mean that training forms that support the motivation of older employees such as training directly targeted at relevant problems at the work place or communication training are more attractive and a participation more efficient for this group of workers.

Kanfer and Ackerman (2004) argue that the motivation for certain tasks changes with age on the basis of the distinction between crystallised and fluid skills. They stress that motivation for training declines with age because a reduction in fluid cognitive ability slows learning and the timeframe for the development of crystallised expertise in which 
performance may be sustained with less effort decreases. Callahan et al. (2003) also argue (but do not find) that the lecture method (that places a relatively heavy demand on cognitive ability) is less effective than more active learning methods. Efficacy in training of skills that do not place heavy demands on fluid intellectual abilities such as conflict management might be higher for lower employees, however.

There are very few empirical analyses on differences in training characteristics and effectiveness during the life cycle. Baethge and Baethge-Kinsky (2004) mention that self-assessed training competence, self-managing disposition and competence development activity do not differ between age groups. Only the anticipation of training needs declines with age in their study. Warr and Birdi (1998) stress that voluntary learning activities and training motivation decline with age. This goes hand in hand with the assessment of personnel managers who say that the strongest disadvantage of older employees is their low trainability and interest in training (Boockmann and Zwick, 2004; Loretto and White, 2006). Self-assessment and the perception of managers both may create a reduced interest in training because peers do not expect regular training participation of older workers and therefore social pressure is lower (Warr and Birdi, 1998).

Beicht et al. (2006) show that there are hardly any differences in the kind of training and the financing of training, people attend during their life cycle. The older the training participants the more modest are the goals associated with training ${ }^{2}$. In addition, older training participants assess the benefits of training more sceptically. The latter results are all significant in multivariate regressions including individual characteristics and

2 The list of goals comprises job security, interesting/more demanding job, higher earnings, better opportunities, higher independence, and other job. 
establishment size. This study includes employees and people outside the labour force, does not take into account differences between these groups, however.

This paper concentrates on differences between training characteristics and training efficiency during the life cycle. On the basis of the theoretical and empirical evidence discussed above, the following three main hypotheses are proposed:

1. Training characteristics (contents, financing, extent) do not change during the life cycle.

It is a problem that employers do not offer age specific training because training motivation and efficiency changes over the life cycle. More specifically:

2. Older employees assess on-the-job and less formal training forms to be more effective in comparison to courses during leisure time and formal training.

3. Older employees assess applied training contents to be more effective than theoretical training contents that cannot be directly be used for topical problems. They also assess training contents in which they do not have a learning disadvantage such as communication and management training to be more effective than training contents that are easier to learn for younger employees such as new technologies.

\section{Data and Estimation Strategy}

The "Berufliche Weiterbildung als Bestandteil Lebenslangen Lernens - Continuing Training as Part of Lifelong Learning" (WeLL) data set combines individual answers on training behaviour with socio-demographic information and some establishment characteristics. So far, there are two waves available from the years 2007 and 2008. The 
first wave entails answers by 6404 employees in 149 enterprises. ${ }^{3}$ The second wave comprises repeated interviews with 4259 employees from the first wave and interviews with 636 newly hired employees from autumn 2008 in the same enterprises. The sample is not representative for the workforce but tailored towards analysing intra-firm processes with respect to continuing training (Bender et al., 2009).

This paper mainly looks at determinants of individual training participation and training characteristics with a focus on employee age. These items are more or less time invariant within less than one year. It therefore does not make sense to include the panel dimension of the data set. In order to avoid biased estimations by including some employees once and other employees twice, all employees from the second wave and only those 4084 employees from the first wave are included who do not have an observation in the second wave. The final sample therefore consists of 6349 employees. In addition, some employees report more than one training episode. In order to avoid that those employees with more than one observation (who probably differ from the other training participants) dominate the results, only one training episode per employee (the first one reported) is taken.

In order to guarantee anonymity, the data do not entail the precise age of the employees but only report whether employees have been born in 1951 or before, between 1952 and 1961, between 1962 and 1971 and in 1972 or after. In 2007, the employees in the oldest age group therefore were at least 56 years old and in 2008, they were at least 57 years old.

Unfortunately, most establishment information is reported only in aggregated form for anonymity reasons. We therefore only know whether an establishment is in the size

\footnotetext{
${ }^{3}$ The individual employee telephone interviews have been conducted between October 2007 and January 2008.
} 
bracket $100-199,200-499$ or 500-1999 employees. In addition, a division between manufacturing and services firms can be made.

Nevertheless, it is possible to integrate the most decisive determinants for training participation of (older) employees (Bannwitz, 2008): gender, qualification, professional position, and motivation on the individual level as well as size and sector on the establishment level. In addition, tenure is added in order not to confound the age and tenure effect on training (Göbel and Zwick, 2009). Finally, two individual characteristics that are closely related to training and easily might be confounded with age are included: self-assessed health and the prospect to leave the labour force within the next year.

\section{Training differences between age groups}

Table 1 shows that the training extent, financing source and the party that took the initiative for training are remarkably similar for older employees in comparison to other age groups. ${ }^{4}$ These findings are analogous to those reported for Germany by Beicht et al. (2006) and for the UK by Taylor and Urwin $(2001)^{5}$ and confirm hypothesis 1 . The WeLL questionnaire also covers training topics (information and communication technology, foreign language, commerce and quality management, technical contents, communication, leadership, environment, health and security) and training forms (seminar, training on the job, job rotation, self-induced learning, professional orientation, quality circles). Descriptive and multivariate analyses reveal that older employees get more or less the same training contents as younger employees. They only participate somewhat more frequently in management and communication training than

\footnotetext{
${ }^{4}$ Coefficients for age groups in multivariate explanations of these training dimensions analogously to those presented further below are accordingly also far from significant (not shown here).

${ }^{5}$ Warr (1993) reports a reduction in time spent in training with age, however.
} 
younger employees. Older employees also get more or less the same training forms as younger employees. They participate somewhat less frequently at training on the job and job rotation but more at presentations and seminars (this is also found for Great Britain, compare Warr, 1993). Participation in the training forms quality circles, professional orientation or self-induced training does not differ significantly between age groups.

Table 2 documents the small differences over the life cycle for the provision of those training contents and forms that are tested on their effectiveness later on. The findings that training form and content are very similar over the age groups are according to hypothesis 1 . Training offers therefore do not take the recommendation into account that informal and unplanned learning should play a greater role for older employees than formal and "normal" learning (Weiss, 2009), that older employees should get more practical and relevant training with quick results (Hertel and Stamov-Rossnagel, 2010), and that older employees dislike training contents that put them at a disadvantage with younger training participants (Kanfer and Ackerman, 2004).

If hypotheses 2 and 3 that older employees prefer other training topics and training forms than young employees are correct, training of older employees should be less effective if employers do not take these differences into account. Indeed, there are significant differences between older and younger training participants with respect to the goals and the effects of training - see Tables 3 and 4. For all dimensions, the oldest age group attributes less importance to important training goals such as higher productivity, higher job security, higher earnings, adaptation to new job, promotion, and new professional orientation. ${ }^{6}$ Younger employees assess the effects of training

\footnotetext{
${ }^{6}$ This is in accordance to findings by Beicht et al. (2006).
} 
significantly more positive than their older colleagues, too. ${ }^{7}$ Only financial and job security effects of training are comparable for the oldest and younger age groups - here only the youngest age group differs significantly. ${ }^{8}$ The literature states that more modest goals associated with training and lower effectiveness of training for older employees are the consequence of a genuinely lower ability and willingness to learn (Warr and Fay, 2001) or of differences in the perception by personnel managers (Koller and Gruber, 2001; Boockmann and Zwick, 2004).

Based on the observation that the training input of older and younger employees are rather similar with respect to extent, training forms and contents, this paper proposes a new explanation why training effectiveness of older employees is lower: Employers do not take the changes in training preferences by age into account. According to our hypotheses we should find that the effectiveness of more abstract and formal training forms (for example: formal seminars) is lower than that of more applied and directly relevant training forms (for example: training on the job or self-induced training). This hypothesis is confirmed by the results on age as a determinant of training effectiveness for different training forms, see Table 5. Note that the relatively high effectiveness of self-motivated training for older employees also might be a consequence of the higher time flexibility that is highly valued by older employees (Callahan et al., 2003).

According to Kanfer and Ackerman (2004), we find that training contents that demand more fluid cognitive ability such as information and communication technology or technical contents have a lower effectiveness for older employees than training in communication and management skills that mainly demand crystallised cognitive ability, compare Table 6. These findings support our third hypothesis that older

\footnotetext{
${ }^{7}$ This also is in accordance to earlier findings by Beicht et al. (2006).

${ }^{8}$ Note that there are no differences between men and women and higher and lower qualified employees with respect to their age-training goals and effectiveness pattern (not shown here).
} 
employees are not keen on comparing themselves with younger training participants in areas in which they have structural disadvantages.

Interestingly, there is no age difference with respect to the satisfaction with training between age groups. This demonstrates that older employees do not structurally answer questions on training more pessimistic or more negative than younger employees. ${ }^{9}$ It is clear, however, that the lower training effectiveness is especially destructive for older employees' training motivation and training participation. It therefore reduces the scope of performance improvements by training (Kanfer and Ackerman, 2004).

In a series of robustness checks, the age effects on training effectiveness and training goals are split by gender, health and the intention to quit employment. These sample splits demonstrate whether the age effects are different for these sub-groups. The youngest and oldest employee groups more often intend to quit employment. ${ }^{10}$ Interestingly, there are no age effects in training effectiveness or training goals for those who intend to quit employment. The age effects therefore completely stem from those employees who intend to stay in the labour market for more than one year. It is not surprising that the share of employees who state that they are healthy declines from $85 \%$ in the youngest group to $69 \%$ in the oldest group. The age effects in training effectiveness and training goals are somewhat smaller for those who state that they are sick, but they do not disappear completely. Finally, the effects of age on training effectiveness and goals are stronger for males than for women (these results are not shown here).

\footnotetext{
${ }^{9}$ See descriptive evidence in Table 1 . A multivariate estimation on the basis of the covariates in Table 2 produces insignificant age coefficients.

${ }^{10}$ The shares are seven, respectively nine percent - the middle age groups have a share of around one percent.
} 


\section{Conclusions}

Training intensity, initiative, payment, content and forms are surprisingly similar over the life cycle. This paper however shows that there are large differences between old and young employees with respect to training goals and the selfassessed effectiveness of training. Employees who are older than 55 years of age pursue training goals such as earnings increases, higher productivity, promotion, job security or adaptation to job changes to a significantly lesser extent than younger employees. This translates into a lower self-assessed effectiveness of training for older employees.

The theoretical literature stresses that older employees prefer training forms that deliver practical and immediately relevant knowledge and training contents that mainly can be mastered by crystallised intelligence. Indeed, this paper shows that the effectiveness of training in communication and management is more effective for older employees than training featuring abstract technical contents or information technology. Self-induced training and training-on-the-job accordingly also is more effective for older employees than participation in seminars and formal training. Unfortunately, firms do not offer these more effective training forms to a larger extent to their older employees. This paper therefore concludes that lower training effectiveness and reduced goals associated with training of older employees are a consequence of firms' offering inadequate training forms and contents.

The management implication of this paper is that the large gap between employers that offer training for older employees and those that offer specific training measures for older employees (Göbel and Zwick, 2010) should decrease. Management has to 
take into consideration the specific training needs and interests of older employees in order to increase training efficiency and the motivation to participate in training.

This paper only reports self assessed answers of training participants. Therefore assessments of (personnel) managers on training effectiveness would be valuable in order to get a complete picture on differences in training over the life cycle. In addition, only few establishment characteristics can be included here. Probably the inclusion of establishment characteristics that potentially are correlated with training effectiveness and the age pattern of training (such as industrial relations, the qualification structure of the establishment or profitability) provide additional explanations for the reduction in training effectiveness for older employees.

\section{Literature}

Addio, A. D', M. Keese and E. Whitehouse (2010): Population Ageing and Labour Markets, Oxford Review of Economic Policy 26 (4), 613-635.

Alferoff, C. (1999): Older Workers: Flexibility, Trust and the Training Relationship, Education and Ageing 14 (1), 51-60.

Armstrong-Stassen, M. and A. Templer (2005): Adapting Training for Older Employees, Journal of Management Development 24 (1), 57-67.

Baethge, M., V. Baethge-Kinsky (2004): Der ungleiche Kampf um das lebenslange Lernen, Waxmann: Münster.

Bannwitz, J. (2008): Ältere Beschäftigte und betriebliche Weiterbildung. Ergebnisse des CVTS 3, Wissenschaftliches Diskussionspapier des BIBB 104, Bonn.

Beicht, U., E. Krekel, G. Walden (2006): Berufliche Weiterbildung: Welche Kosten und welchen Nutzen haben die Teilnehmenden? Bertelsmann: Bielefeld. 
Bellmann, L., U. Leber (2004): Ältere Arbeitnehmer und betriebliche Weiterbildung, in G. Schmid, Gangl, M., Kupka, P. (eds.): Arbeitsmarktpolitik und Strukturwandel: Empirische Analysen, Beiträge zur Arbeitsmarkt- und Berufsforschung, Nürnberg.

Bender, S., M. Fertig, K. Görlitz, M. Huber and A. Schmucker (2009), WeLL - Unique Linked Employer-Employee Data on Further Training in Germany. Schmollers Jahrbuch 129 (4): 637-643.

Boockmann, B. and T. Zwick (2004): Betriebliche Determinanten der Beschäftigung älterer Arbeitnehmer. Zeitschrift für ArbeitsmarktForschung, 37 (1), 53-63.

Callahan, J., D. Kiker, T. Cross (2003): Does Method Matter? A Meta-Analysis of the Effects of Training Method on Older Learner Training Performance, Journal of Management 29 (5), 663-380.

Cunha, F., J. Heckman, L. Lochner and D. Masterov (2006): Interpreting the Evidence on Life Cycle Skill Formation, in: Hanushek, E. and F. Welch (eds.) Handbook of the Economics of Education, North Holland: Amsterdam, 697-812.

Gallenberger, W. (2002): Weiterbildungsabstinenz älterer Beschäftigter in einer alternden Erwerbsbevölkerung? Opladen.

Göbel, C. and T. Zwick (2010): Age and Productivity - Evidence from Linked Employer Employee Data, ZEW Discussion Paper No. 010-020, Mannheim.

Huber, M. (2009), Frauen ab 50 - Bedürfnisse und betriebliche Barrieren im Bereich der beruflichen Weiterbildung. In B. Blättel-Mink und C. Kramer (Hrsg.), Doing Aging - Weibliche Perspektiven des Älterwerdens. Schriften des Heidelberger Instituts für Interdisziplinäre Frauen- und Geschlechterforschung 7. Baden-Baden: Nomos, 127-138.

Kanfer, R. and P. Ackerman (2004): Aging, Adult Development and Work Motivation, Academy of Management Review 29, 440-458. 
Koller, B. and H. Gruber (2001): Ältere Arbeitnehmer im Betrieb und als Stellenbewerber aus der Sicht der Personalverantwortlichen, Mitteilungen aus der Arbeitsmarkt- und Berufsforschung 34, 479-505.

Lois, D. (2007): Determinanten der Weiterbildungsbeteiligung älterer Erwerbstätiger, Zeitschrift für Arbeitsmarktforschung, Arbeitsgestaltung und Arbeitspolitik 16 (1), 5-

22.

Loretto, W. and P. White (2006): Employers' Attitudes, Practices and Policies Towards Older Workers, Human Resource Management Journal 16 (3), 313-330.

Rosenbladt, B. von, F. Bilger (2008): Weiterbildungsbeteiligung in Detuschland Eckdaten zum BSW-AES 2007, BMBF: München.

Stamov-Roßnagel, C. and G. Hertel (2010): Older Worker's Motivation: Against the Myth of General Decline, Management Decision 48 (6), 894-906.

Taylor, P., P. Urwin (2001): Age and Participation in Vocation Education and Training, Work, Employment and Society 15 (4), 763-779.

Tippelt, R., B. Schmidt, S. Schnurr, S. Sinner, Catharina Theisen (2009): Bildung Älterer - Chancen im demographischen Wandel, Bertelsmann, Bielefeld.

Warr, P. (1993): Training for Older Managers, Human Resource Management Journal 4 (2), 22-38.

Warr, P. and K. Birdi (1998): Employee Age and Voluntary Development Activity, International Journal of Training and Development 2, 190-204.

Warr, P. and D. Fay (2001): Short report: age and personal initiative at work, European Journal of Work and Organizational Psychology: 10 (3), 343-353. 
Weiss, R. (2009): Ausgelernt? Befunde, Interpretation und Empfehlungen zum lebensbegleitenden Lernen älterer Menschen, in: U. Staudinger and H. Heidemeier (eds.): Altern Bildung und lebenslanges Lernen, Altern in Deutschland 2, Nova Acta Leopoldina Neue Folge Band 100, Wissenschaftliche Verlagsgesellschaft: Stuttgart. 


\section{Tables}

Table 1: Descriptive Differences between Training Dimensions and Age Groups

\begin{tabular}{|c|c|c|c|c|c|}
\hline Training & Entire & Birth Year & Birth Years & Birth Years & Birth Year \\
\hline Dimension & Sample & $\begin{array}{l}1951 \text { or } \\
\text { older }\end{array}$ & 1952-1961 & $1962-1971$ & $\begin{array}{l}1972 \text { or } \\
\text { younger }\end{array}$ \\
\hline $\begin{array}{l}\text { Duration in } \\
\text { hours }\end{array}$ & $\begin{array}{l}44.57 \\
(104.32)\end{array}$ & $\begin{array}{l}41.71 \\
(87.87)\end{array}$ & $\begin{array}{l}47.77 \\
(115.28)\end{array}$ & $\begin{array}{l}43.30 \\
(101.07)\end{array}$ & $\begin{array}{l}42.36 \\
(97.79)\end{array}$ \\
\hline $\begin{array}{l}\text { Period in } \\
\text { months }\end{array}$ & $\begin{array}{l}2.32 \\
(1.89)\end{array}$ & $\begin{array}{l}2.29 \\
(1.87)\end{array}$ & $\begin{array}{l}2.31 \\
(1.87)\end{array}$ & $\begin{array}{l}2.34 \\
(1.91)\end{array}$ & $\begin{array}{l}2.34 \\
(1.93)\end{array}$ \\
\hline $\begin{array}{l}\text { Number of } \\
\text { trainings }\end{array}$ & $\begin{array}{l}1.77 \\
(1.12)\end{array}$ & $\begin{array}{l}1.77 \\
(1.39)\end{array}$ & $\begin{array}{l}1.74 \\
(1.13)\end{array}$ & $\begin{array}{l}1.78 \\
(1.26)\end{array}$ & $\begin{array}{l}1.80 \\
(1.25)\end{array}$ \\
\hline Costs borne by & 0.16 & 0.15 & 0.15 & 0.16 & 0.17 \\
\hline $\begin{array}{l}\text { participant } \\
\text { Initiative by }\end{array}$ & $\begin{array}{l}(0.36) \\
0.41\end{array}$ & $\begin{array}{l}(0.35) \\
0.41\end{array}$ & $\begin{array}{l}(0.37) \\
0.42\end{array}$ & $\begin{array}{l}(0.36) \\
0.41\end{array}$ & $\begin{array}{l}(0.38) \\
0.42\end{array}$ \\
\hline participant & $(0.49)$ & $(0.49)$ & $(0.49)$ & $(0.49)$ & $(0.49)$ \\
\hline $\begin{array}{l}\text { Initiative by } \\
\text { employer }\end{array}$ & $\begin{array}{l}0.23 \\
(0.42)\end{array}$ & $\begin{array}{l}0.23 \\
(0.42)\end{array}$ & $\begin{array}{l}0.23 \\
(0.42)\end{array}$ & $\begin{array}{l}0.23 \\
(0.42)\end{array}$ & $\begin{array}{l}0.22 \\
(0.41)\end{array}$ \\
\hline $\begin{array}{l}\text { Training } \\
\text { necessary by } \\
\text { law }\end{array}$ & $\begin{array}{l}0.17 \\
(0.38)\end{array}$ & $\begin{array}{l}0.16 \\
(0.37)\end{array}$ & $\begin{array}{l}0.18 \\
(0.38\end{array}$ & $\begin{array}{l}0.18 \\
(0.38)\end{array}$ & $\begin{array}{l}0.17 \\
(0.37)\end{array}$ \\
\hline $\begin{array}{l}\text { Training } \\
\text { satisfaction }\end{array}$ & $\begin{array}{l}5.74 \\
(2.64)\end{array}$ & $\begin{array}{l}5.58 \\
(2.77)\end{array}$ & $\begin{array}{l}5.74 \\
(2.69)\end{array}$ & $\begin{array}{l}5.73 \\
(2.60)\end{array}$ & $\begin{array}{l}5.92 \\
(2.50)\end{array}$ \\
\hline
\end{tabular}

Comment: Standard deviation in brackets. 
Table 2: Determinants of Selected Training Characteristics

\begin{tabular}{|c|c|c|c|c|c|c|}
\hline & $\begin{array}{l}\text { Self- } \\
\text { induced } \\
\text { learning }\end{array}$ & Seminar & $\begin{array}{l}\text { Training } \\
\text { on the job }\end{array}$ & $\begin{array}{l}\text { ICT } \\
\text { Training }\end{array}$ & $\begin{array}{l}\text { Technical } \\
\text { Training }\end{array}$ & $\begin{array}{l}\text { Communication } \\
\text { and } \\
\text { Management } \\
\text { Training }\end{array}$ \\
\hline $\begin{array}{l}\text { Birth years } \\
1952-61\end{array}$ & 0.01 & -0.01 & $0.04 *$ & -0.00 & -0.00 & $-0.02^{*}$ \\
\hline $\begin{array}{l}\text { Birth years } \\
1962-71\end{array}$ & -0.02 & -0.01 & $0.08 * * *$ & -0.00 & -0.01 & -0.01 \\
\hline $\begin{array}{l}\text { Birth years } \\
1972 \text { and } \\
\text { younger }\end{array}$ & -0.01 & $-0.04 * *$ & $0.12 * * *$ & $-0,01$ & -0.02 & -0.00 \\
\hline R-squared & 0.03 & 0.08 & 0.01 & 0.00 & 0.00 & 0.00 \\
\hline Obs. & 5590 & 5590 & 5590 & 5590 & 5590 & 5590 \\
\hline
\end{tabular}

Comments: OLS regressions, clustering adjusted for 149 enterprises, same covariates as in Table 3. 
Table 3: Determinants of Training Goals

\begin{tabular}{|c|c|c|c|c|c|c|}
\hline & $\begin{array}{l}\text { Higher } \\
\text { Productivity }\end{array}$ & Adoption & Promotion & $\begin{array}{l}\text { Higher } \\
\text { Earnings }\end{array}$ & $\begin{array}{l}\text { Job } \\
\text { Security }\end{array}$ & $\begin{array}{l}\text { New } \\
\text { Orientation }\end{array}$ \\
\hline Realschule & $0.12 * * *$ & $0.11 * * *$ & 0.03 & 0.02 & $0.05 * * *$ & 0.01 \\
\hline Gymnasium & $0.24 * * *$ & $0.21 * * *$ & $0.08 * * *$ & 0.01 & 0.03 & $0.04 * * *$ \\
\hline Female & -0.00 & 0.01 & $-0.05 * * *$ & $-0.04 * * *$ & 0.02 & -0.01 \\
\hline $\begin{array}{l}\text { Birth years } \\
1952-61\end{array}$ & $0.06 * * *$ & $0.06 * * *$ & $0.08 * *$ & $0.06 * * *$ & $0.07 * * *$ & $0.02 *$ \\
\hline $\begin{array}{l}\text { Birth years } \\
1962-71\end{array}$ & $0.04 * *$ & $0.05 * * *$ & $0.11 * * *$ & $0.10 * * *$ & $0.05^{* * *}$ & $0.05 * * *$ \\
\hline $\begin{array}{l}\text { Birth years } \\
1972 \text { and } \\
\text { younger }\end{array}$ & $0.09 * * *$ & $0.08 * * *$ & $0.21 * * *$ & $0.16 * * *$ & $0.10 * * *$ & $0.10 * * *$ \\
\hline $\begin{array}{l}\text { Tenure 2-5 } \\
\text { years }\end{array}$ & $0.06^{* *}$ & $0.06 * *$ & 0.03 & 0.03 & $0.06^{* *}$ & $0.04 *$ \\
\hline $\begin{array}{l}\text { Tenure 6-15 } \\
\text { years }\end{array}$ & $0.05 * * *$ & $0.06 * * *$ & $0.05 * * *$ & $0.05 * * *$ & $0.06^{* * *}$ & $0.03 *$ \\
\hline $\begin{array}{l}\text { Tenure } \\
\text { more than } \\
15 \text { years }\end{array}$ & $0.05^{* * *}$ & $0.05 * * *$ & $0.04 * * *$ & $0.04 * *$ & $0.05^{* * *}$ & 0.01 \\
\hline Good health & $0.05 * * *$ & $0.04 * *$ & $0.04 * * *$ & $0.05 * * *$ & $0.04 * *$ & 0.01 \\
\hline $\begin{array}{l}\text { High } \\
\text { probability } \\
\text { to quit } \\
\text { working }\end{array}$ & $-0.11 * * *$ & $-0.11 * * *$ & $-0.08 * *$ & $-0.08 * * *$ & $-0.12 * * *$ & -0.03 \\
\hline $\begin{array}{l}\text { East } \\
\text { Germany }\end{array}$ & -0.01 & -0.00 & $-0.02 *$ & 0.00 & 0.01 & -0.01 \\
\hline $\begin{array}{l}\text { 200-499 } \\
\text { employees }\end{array}$ & 0.01 & 0.03 & 0.02 & 0.01 & 0.01 & $0.03 * *$ \\
\hline $\begin{array}{l}\text { 500-1999 } \\
\text { employees }\end{array}$ & $0.05 *$ & $0.05 * *$ & $0.04 *$ & $0.04 * *$ & $0.05 * *$ & $0.03 * *$ \\
\hline $\begin{array}{l}\text { Services } \\
\text { sector }\end{array}$ & $0.04 * *$ & $0.04 * *$ & 0.00 & -0.00 & 0.02 & 0.01 \\
\hline R-squared & 0.03 & 0.04 & 0.04 & 0.02 & 0.02 & 0.02 \\
\hline
\end{tabular}

Comments: OLS regressions, clustering adjusted for 149 enterprises, number of observations: 5303, reference categories: Hauptschule, birth year 1952 or older, employer with less than 200 and more than 50 employers, tenure less than 2 years. 
Table 4: Determinants of Training Effects

\begin{tabular}{|c|c|c|c|c|c|c|}
\hline & $\begin{array}{l}\text { Higher } \\
\text { Productivity }\end{array}$ & Adoption & Promotion & $\begin{array}{l}\text { Higher } \\
\text { Earnings }\end{array}$ & $\begin{array}{l}\text { Job } \\
\text { Security }\end{array}$ & $\begin{array}{l}\text { New } \\
\text { Orientation }\end{array}$ \\
\hline Realschule & $0.09 * * *$ & 0.06 & 0.01 & 0.00 & $0.03 * *$ & 0.01 \\
\hline Gymnasium & $0.17 * * *$ & $0.04 * * *$ & $0.04 * * *$ & -0.00 & 0.02 & $0.07 * * *$ \\
\hline Female & 0.02 & $-0.02 * * *$ & $-0.02 * * *$ & $-0.01 * * *$ & $-0.02 *$ & -0.01 \\
\hline $\begin{array}{l}\text { Birth years } \\
1952-61\end{array}$ & $0.05 * *$ & $0.04 * *$ & $0.02 * *$ & 0.00 & 0.02 & $0.02 *$ \\
\hline $\begin{array}{l}\text { Birth years } \\
1962-71\end{array}$ & 0.03 & $0.03 *$ & $0.05 * * *$ & 0.01 & 0.02 & $0.04 * * *$ \\
\hline $\begin{array}{l}\text { Birth years } \\
1972 \text { and } \\
\text { younger }\end{array}$ & $0.06^{* *}$ & $0.09 * * *$ & $0.11 * * *$ & $0.05 * * *$ & $0.06 * * *$ & $0.11^{* * *}$ \\
\hline $\begin{array}{l}\text { Tenure 2-5 } \\
\text { years }\end{array}$ & $0.06^{* *}$ & $0.05 * *$ & $0.02 *$ & 0.01 & 0.04 & $0.03 * *$ \\
\hline $\begin{array}{l}\text { Tenure 6-15 } \\
\text { years }\end{array}$ & $0.08 * * *$ & $0.07 * * *$ & $0.02 * *$ & 0.01 & $0.03 *$ & $0.02 *$ \\
\hline $\begin{array}{l}\text { Tenure } \\
\text { more than } \\
15 \text { years }\end{array}$ & $0.06 * * *$ & $0.05 * * *$ & $0.02 * *$ & 0.01 & $0.03 * *$ & 0.01 \\
\hline Good health & $0.05 * * *$ & 0.03 & $0.02 * * *$ & $0.02 * * *$ & $0.04 * * *$ & 0.01 \\
\hline $\begin{array}{l}\text { High } \\
\text { probability } \\
\text { to quit } \\
\text { working }\end{array}$ & $-0.10 * * *$ & $-0.09 * * *$ & $-0.04 * *$ & -0.01 & $-0.06^{* *}$ & -0.00 \\
\hline $\begin{array}{l}\text { East } \\
\text { Germany }\end{array}$ & -0.01 & -0.00 & -0.01 & -0.01 & 0.01 & $-0.02 * *$ \\
\hline $\begin{array}{l}\text { 200-499 } \\
\text { employees }\end{array}$ & 0.01 & 0.03 & 0.01 & 0.00 & 0.01 & 0.00 \\
\hline $\begin{array}{l}\text { 500-1999 } \\
\text { employees }\end{array}$ & $0.05 *$ & $0.06 * *$ & $0.03 * * *$ & 0.01 & 0.02 & 0.01 \\
\hline $\begin{array}{l}\text { Services } \\
\text { sector }\end{array}$ & $0.04 * *$ & $0.05 * *$ & -0.00 & $-0.02 * * *$ & 0.00 & 0.00 \\
\hline R-squared & 0.03 & 0.03 & 0.03 & 0.01 & 0.01 & 0.03 \\
\hline
\end{tabular}

Comments: OLS regressions, clustering adjusted for 149 enterprises, number of observations: 5303, reference categories: Hauptschule, birth year 1952 or older, employer with less than 200 and more than 50 employers, tenure less than 2 years 
Table 5: Self-Assessed Effectiveness of Different Training Forms

\begin{tabular}{|c|c|c|c|c|c|c|}
\hline $\begin{array}{l}\text { Effects of } \\
\text { training }\end{array}$ & $\begin{array}{l}\text { Higher } \\
\text { Productivity }\end{array}$ & Adoption & Promotion & $\begin{array}{l}\text { Higher } \\
\text { Earnings }\end{array}$ & $\begin{array}{l}\text { Job } \\
\text { Security }\end{array}$ & $\begin{array}{l}\text { New } \\
\text { Orientation }\end{array}$ \\
\hline $\begin{array}{l}\text { Seminar } \\
\text { Birth years } \\
1952-61\end{array}$ & $0.08 *$ & $0.09 * *$ & $0.03 *$ & 0.01 & $0.09 * * *$ & $0.07 * * *$ \\
\hline $\begin{array}{l}\text { Birth years } \\
1962-71\end{array}$ & $0.09 * *$ & $0.11 * *$ & $0.09 * * *$ & $0.03 *$ & $0.10 * * *$ & $0.13 * * *$ \\
\hline $\begin{array}{l}\text { Birth years } 1972 \\
\text { and younger } \\
\text { Training on the } \\
\text { job }\end{array}$ & 0.04 & $0.09 *$ & $0.15 * * *$ & $0.05^{*}$ & $0.09 * *$ & $0.21 * * *$ \\
\hline $\begin{array}{l}\text { Birth years } \\
\text { 1952-61 }\end{array}$ & 0.01 & 0.02 & $0.03 *$ & 0.01 & -0.01 & 0.02 \\
\hline $\begin{array}{l}\text { Birth years } \\
1962-71\end{array}$ & 0.01 & 0.04 & $0.04 * *$ & 0.02 & 0.00 & $0.06^{* *}$ \\
\hline $\begin{array}{l}\text { Birth years } 1972 \\
\text { and younger } \\
\text { Self-managed } \\
\text { learning }\end{array}$ & $0.07 *$ & $0.09 * *$ & $0.11 * * *$ & $0.05 * * *$ & 0.02 & $0.12 * * *$ \\
\hline $\begin{array}{l}\text { Birth years } \\
1952-61\end{array}$ & 0.02 & $0.01 *$ & 0.03 & -0.01 & 0.04 & 0.04 \\
\hline $\begin{array}{l}\text { Birth years } \\
1962-71\end{array}$ & -0.01 & 0.08 & 0.05 & 0.01 & 0.02 & $0.08 * * *$ \\
\hline $\begin{array}{l}\text { Birth years } 1972 \\
\text { and younger }\end{array}$ & 0.07 & 0.09 & $0.09 * * *$ & $0.05 *$ & 0.06 & $0.07 * * *$ \\
\hline
\end{tabular}

Comments: OLS regressions, Number of observations (enterprises): seminar: 1401 (142), training on the job: 2104 (146), self-managed learning: 950 (134); R-squared: seminar $<=0.04$, training on the job $<=0.05$, self-managed learning $<=0.06$; same covariates as in Table 3. 
Table 6: Self-Assessed Effectiveness of Different Training Contents

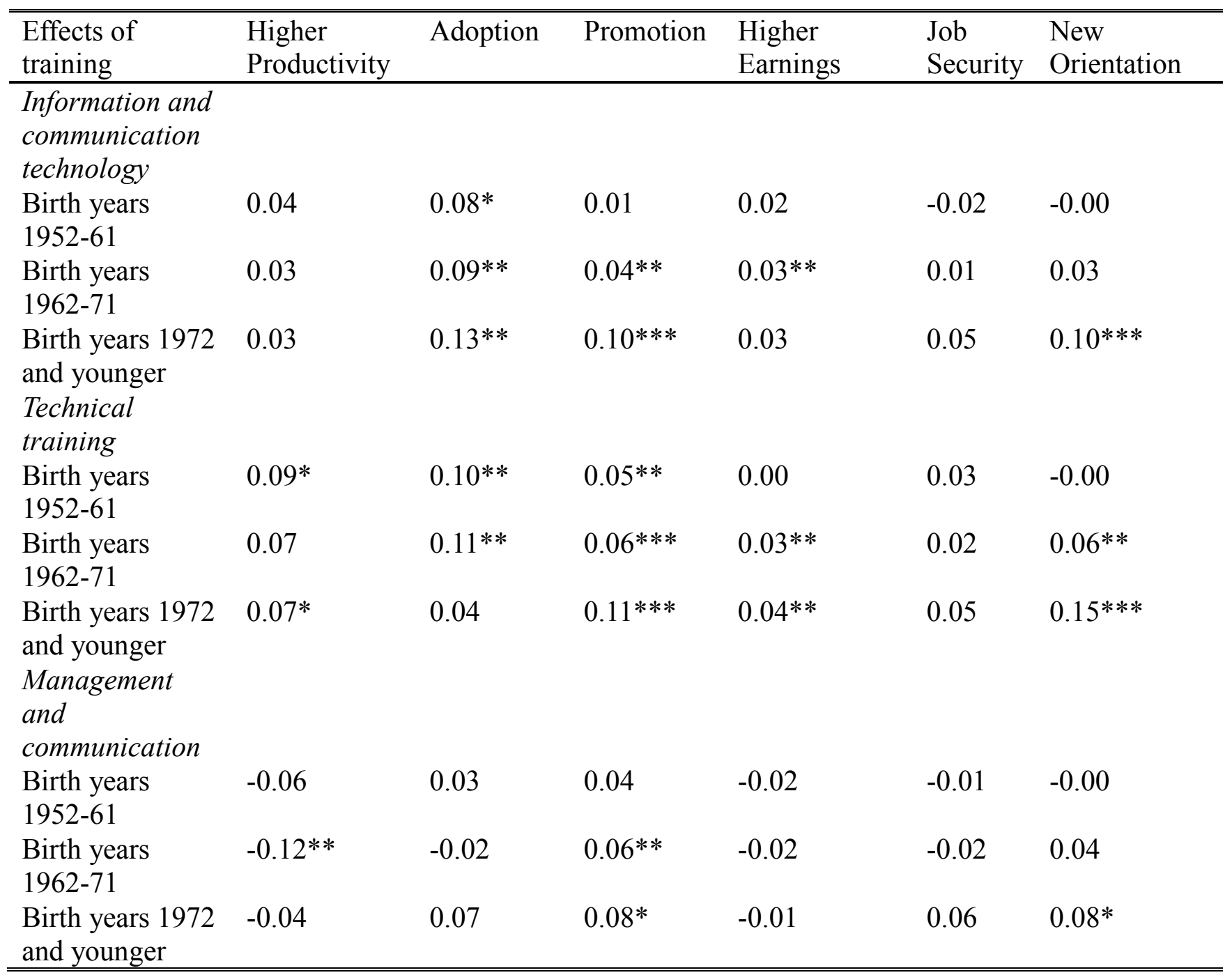

Comments: OLS regressions, Number of observations (enterprises): information and communication technology: 937 (141), technical contents: 1009 (143), management and communication: 554 (127); R-squared: information and communication technology $<=0.06$, technical content $<=0.06$, management and communication $<=0.07$; same covariates as in Table 3. 


\section{Appendix}

Appendix Table 1: Descriptive Statistics of dependent training variables

\begin{tabular}{|c|c|c|c|}
\hline Variable Name & Mean & Std. Dev. & $\overline{\text { Description }}$ \\
\hline \multicolumn{4}{|l|}{ Training effects } \\
\hline $\begin{array}{l}\text { Higher } \\
\text { Productivity }\end{array}$ & 0.38 & 0.48 & Higher productivity important effect of training \\
\hline Adoption & 0.34 & 0.47 & $\begin{array}{l}\text { Adoption to new challenges important effect of } \\
\text { training }\end{array}$ \\
\hline Promotion & 0.08 & 0.27 & $\begin{array}{l}\text { Promotion to higher hierarchy important effect } \\
\text { of training }\end{array}$ \\
\hline $\begin{array}{l}\text { Higher } \\
\text { Earnings }\end{array}$ & 0.03 & 0.18 & Higher earnings important effect of training \\
\hline Job Security & 0.23 & 0.42 & Higher job security important effect of training \\
\hline $\begin{array}{l}\text { New } \\
\text { Orientation }\end{array}$ & 0.08 & 0.28 & $\begin{array}{l}\text { New professional orientation important effect } \\
\text { of training }\end{array}$ \\
\hline \multicolumn{4}{|c|}{ Important training goals } \\
\hline $\begin{array}{l}\text { Higher } \\
\text { Productivity }\end{array}$ & 0.51 & 0.50 & Higher productivity important goal of training \\
\hline Adoption & 0.46 & 0.50 & Adoption to new challenges goal of training \\
\hline Promotion & 0.25 & 0.44 & Promotion to higher hierarchy goal of training \\
\hline $\begin{array}{l}\text { Higher } \\
\text { Earnings }\end{array}$ & 0.29 & 0.45 & Higher earnings important goal of training \\
\hline Job Security & 0.37 & 0.48 & Higher job security important goal of training \\
\hline $\begin{array}{l}\text { New } \\
\text { Orientation }\end{array}$ & 0.12 & 0.32 & $\begin{array}{l}\text { New professional orientation important goal of } \\
\text { training }\end{array}$ \\
\hline \multicolumn{4}{|c|}{ Training forms and contents } \\
\hline $\begin{array}{l}\text { Technical } \\
\text { content }\end{array}$ & 0.18 & 0.38 & Technical content training \\
\hline ICT training & 0.17 & 0.37 & $\begin{array}{l}\text { Information and communication technology } \\
\text { training }\end{array}$ \\
\hline $\begin{array}{l}\text { Communication } \\
\text { management } \\
\text { training }\end{array}$ & 0.10 & 0.29 & Communication and management training \\
\hline $\begin{array}{l}\text { Self-induced } \\
\text { training }\end{array}$ & 0.17 & 0.37 & Training form was self-induced training \\
\hline Seminar & 0.25 & 0.43 & Training form was a seminar \\
\hline $\begin{array}{l}\text { Training on the } \\
\text { job }\end{array}$ & 0.38 & 0.48 & Training form was on the job training \\
\hline
\end{tabular}


Appendix Table 2: Descriptive Statistics of explanatory variables

\begin{tabular}{|c|c|c|c|}
\hline Variable Name & Mean & $\begin{array}{l}\text { Standard } \\
\text { Deviation }\end{array}$ & Description \\
\hline Hauptschule & 0.22 & 0.41 & $\begin{array}{l}\text { Employees with highest schooling degree } \\
\text { Hauptschule }\end{array}$ \\
\hline Realschule & 0.43 & 0.49 & $\begin{array}{l}\text { Employees with highest schooling degree } \\
\text { Realschule }\end{array}$ \\
\hline Gymnasium & 0.34 & 0.47 & $\begin{array}{l}\text { Employees with highest schooling degree } \\
\text { Gymnasium }\end{array}$ \\
\hline Female & 0.38 & 0.49 & Female yes/no \\
\hline $\begin{array}{l}\text { Birth years } \\
1951 \text { or older }\end{array}$ & 0.14 & 0.35 & $\begin{array}{l}\text { Employees born in year } 1951 \text { or before (aged } \\
55 / 57 \text { or older) }\end{array}$ \\
\hline $\begin{array}{l}\text { Birth years } \\
1952-61\end{array}$ & 0.37 & 0.48 & $\begin{array}{l}\text { Employees born in years 1952-1961 (aged } \\
46 / 47-55 / 56 \text { ) }\end{array}$ \\
\hline $\begin{array}{l}\text { Birth years } \\
1962-71\end{array}$ & 0.33 & 0.47 & $\begin{array}{l}\text { Employees born in years 1962-1971 (aged } \\
36 / 37-45 / 46 \text { ) }\end{array}$ \\
\hline $\begin{array}{l}\text { Birth years } \\
1972 \text { and } \\
\text { younger }\end{array}$ & 0.16 & 0.37 & $\begin{array}{l}\text { Employees born in year } 1972 \text { or after (aged } 35 \\
\text { or younger) }\end{array}$ \\
\hline Tenure $<2$ & 0.12 & 0.32 & Tenure less than 2 years \\
\hline $\begin{array}{l}\text { Tenure } 2-5 \\
\text { years }\end{array}$ & 0.10 & 0.29 & Tenure between 2 and 5 years \\
\hline $\begin{array}{l}\text { Tenure } 6-15 \\
\text { years }\end{array}$ & 0.26 & 0.44 & Tenure between 6 and 15 years \\
\hline $\begin{array}{l}\text { Tenure more } \\
\text { than } 15 \text { years }\end{array}$ & 0.42 & 0.49 & Tenure more than 15 years \\
\hline Good health & 0.78 & 0.41 & Topical health situation good or very good \\
\hline $\begin{array}{l}\text { High } \\
\text { probability to } \\
\text { quit }\end{array}$ & 0.03 & 0.18 & $\begin{array}{l}\text { High self-assessed probability to quit } \\
\text { employment within next } 12 \text { months }\end{array}$ \\
\hline East Germany & 0.39 & 0.49 & Workplace located in East Germany \\
\hline $\begin{array}{l}\text { 100-199 } \\
\text { employees }\end{array}$ & 0.14 & 0.35 & $\begin{array}{l}\text { Establishment has between } 100 \text { and } 199 \\
\text { employees }\end{array}$ \\
\hline $\begin{array}{l}\text { 200-499 } \\
\text { employees }\end{array}$ & 0.24 & 0.43 & $\begin{array}{l}\text { Establishment has between } 200 \text { and } 499 \\
\text { employees }\end{array}$ \\
\hline $\begin{array}{l}\text { 500-1999 } \\
\text { employees }\end{array}$ & 0.61 & 0.49 & $\begin{array}{l}\text { Establishment has between } 500 \text { and } 1999 \\
\text { employees }\end{array}$ \\
\hline Services sector & 0.49 & 0.50 & Establishment in services sector \\
\hline
\end{tabular}

